\title{
Determination of Investment Needs to Pursue Growth Targets through Incremental Capital Output Ratio (ICOR)
}

\author{
Suparmono ${ }^{\bowtie}$ \\ Sekolah Tinggi Ilmu Manajemen YKPN \\ e-mail: suparmono@stimykpn.ac.id
}

\begin{abstract}
This article aims to analyze the effectiveness of investment as measured by the need for investment to produce output at a certain level, which in turn can determine the regional economic growth target. The analytical tool used is the incremental capital output ratio (ICOR) and the determination of economic growth targets. The ICOR value used in this study was calculated using three calculation approaches, namely Lag0, Lag1, and Lag2 data. The data used in this study is data from the economy of the Special Region of Yogyakarta until 2019. The result is that during the research period, there is a correlation between ICOR and economic growth, meaning that the lower the ICOR value, the value of economic growth will also increase. This shows that the effectiveness and efficiency of investment will result in a positive impact on economic growth.
\end{abstract}

Keywords: ICOR, economic growth, investment, regional economy, spacial economy

\begin{abstract}
Abstrak
Artikel ini bertujuan untuk menganalisis efektivitas investasi yang diukur dengan kebutuhan investasi untuk menghasilkan output pada tingkat tertentu, yang pada gilirannya dapat menentukan target pertumbuhan ekonomi daerah. Alat analisis yang digunakan adalah incremental capital output ratio (ICOR) dan penentuan target pertumbuhan ekonomi. Nilai ICOR yang digunakan dalam penelitian ini dihitung dengan menggunakan tiga pendekatan perhitungan, yaitu data Lag0, Lag1, dan Lag2. Data yang digunakan dalam penelitian ini adalah data perekonomian Daerah Istimewa Yogyakarta sampai tahun 2019. Hasil penelitian selama periode penelitian terdapat korelasi antara ICOR dengan pertumbuhan ekonomi, artinya semakin rendah nilai ICOR maka nilai pertumbuhan ekonomi juga akan meningkat. Hal ini menunjukkan bahwa efektivitas dan efisiensi investasi akan berdampak positif terhadap pertumbuhan ekonomi.
\end{abstract}

Kata kunci: ICOR, pertumbuhan ekonomi, investasi, ekonomi regional, ekonomi spasial 


\section{INTRODUCTION}

Investments are a foundation of a competitive economy and a key tool for the economic system's functioning, raising worker productivity and, as a result, enhancing the population's living standards (Samoylova et al., 2020). Improving the effectiveness of regional investment policies is critical for the development of all subjects (Samoylova et al., 2020).

There is a link between economic growth and investment, especially investment in infrastructure (Jiang et al., 2019). Theoretical and empirical studies have shown that the stock of private and public capital has a positive and significant impact on economic growth (Soumaila, 2017; Sedova \& Filatov, 2020). In measuring how much additional investment should be needed to increase every one unit in percent of economic growth, to be able to calculate it requires a commonly used calculation ratio such as the Incremental Capital Output Ratio (ICOR). ICOR is a part of descriptive statistics developed specifically related to macroeconomic investment studies (Masloman et al., 2020).

Basically the theory of ICOR is based on two kinds of concepts (Masloman et al., 2020) (Nevyantseva \& Vlasova, 2021). First, Capital-Output Ratio (COR) or often referred to as the Average Capital Output Ratio (ACOR), which is the ratio between the capital used and the output produced in a certain period. COR or ACOR is static because it only shows a quantity that describes the ratio of capital and output. Second, Marginal Capital-Output Ratio or Incremental Capital Output Ratio (ICOR) is a quantity that shows the amount of additional new capital (investment) needed to increase/add one unit of output both physically and in value (money). The ICOR concept is more dynamic because it shows changes/increases in output as a direct result of the addition of capital.

Worse, machines and equipment are constantly being phased out as a result of depreciation and must be replaced, requiring a portion of the investment to be spent on this. As capacities grow, this proportion rises steadily until it reaches unity. Then, and only then, will all investments be directed toward replenishing a massive reserve of perpetually deteriorating capacities, and their growth is being installed. The economy loses the only source of growth and goes into a stationary state (Thach, 2020).

However, there are also opinions from economists, that changes in interest rates will affect the efficiency of the aggregative economy. Because, if we talk about interest rates, then we will also mention the problem investation (Ehigiamusoe \& Lean, 2019). The issue of investment (investment) is closely related to the concept of the Incremental Capital Output Ratio (ICOR). The definition of ICOR, how to calculate it and the real conditions in Indonesia will be presented in a separate chapter. But that sure, high The low COR ratio reflects the macroeconomic efficiency of a country. Departing from the background This study aims to determine what factors are the cause of the high ICOR and determine the effect of changes in real interest rates on ICOR as well as identify and measure the efficiency level of the national economy (Mahmud, 2008; (Masloman et al., 2020).

ICOR is simply defined as a quantity that shows the number of additional production capacity or investment required to increase output by one unit (Huggins et al., 2014; $\mathrm{Ru}$ et al., 2020). Or mathematically the ICOR coefficient is expressed as the ratio between the addition of investment $(\Delta \mathrm{I})$ to the addition of output $(\Delta \mathrm{Y})$. Actually the additional output is not only influenced by the investment factor invested, but also influenced by other variables, such as: growth in productivity, utilization of production capacity. Other factors that also affect investment are technological progress and employment. However, in calculating ICOR it is assumed that these other factors are held constant. In calculating ICOR, the investment concept used refers to the concept of national 
economy. The definition of investment referred to here is fixed capital formation/establishment of fixed capital goods consisting of land, buildings/construction, machinery and equipment, vehicles and other capital goods. Meanwhile, the calculated values include (1) purchase of new/used goods, (2) major manufacture/repair made by other parties, (3) do-it-yourself major build/repair, and (4) sales of used capital goods Fixed Capital Formation/Formation of Fixed Capital Goods in this case is the Formation of Gross Fixed Capital Goods (Maradana et al., 2019).

\section{METHODS}

ICOR's relationship with economic growth was first developed by R.F. Harrod and Evsey Domar. Professor Evsey Domar, an American economist, developed a coefficient derived from a formula for economic growth (Walters, 1966). Domar Harrod Domar's model relates the effect of additional capital stock on output which is known as ICOR. ICOR calculation is needed to see how efficient the investment invested in an area is in a certain period. The size of the investment needs needed to be able to meet a certain regional income target or rate of economic growth is given by a measure or economic indicator called the Incremental Capital Output Ratio (Campano et al., 2017).

$I C O R=f($ rit $, g, y r$, rit -1$)$

Where

ICOR = Incremental Capital Output Ratio,

rit $=$ real interest rate,

g = GDP growth,

$\mathrm{Yr} \quad=$ rit-1 calendar, and

year $=$ one month lag of real interest rates.

In the Harrod-Domar growth model includes the equation as following:

$K=v Y$

$L=u Y$

$I=S$
$S=s Y$

$\Delta L / L=n$

Based on Equations (2) and (3) it can be formulated the function equation production as follows:

$Y=A \min (K / v, L / u)$

$$
\begin{aligned}
& \text { Where } \\
& \mathrm{Y}=\text { Output } \\
& \text { A } \quad=\text { Technology } \\
& \mathrm{K}=\text { Capital stock } \\
& \mathrm{L} \quad=\text { Number of workers } \\
& \text { I }=\text { Investment } \\
& \mathrm{S}=\text { Total savings } \\
& \mathrm{v} \quad=\text { Ratio of capital to output } \\
& \mathrm{u}=\text { Labor-to-output ratio } \\
& \mathrm{s} \quad=\text { Saving rate } \\
& \mathrm{n}=\text { natural labor growth rate }
\end{aligned}
$$

Assuming $\mathrm{A}=1$, then to obtain a change in output of $Y$, it is necessary to change the input as follows:

$\left.H 1^{\prime}\right) \Delta K=v \Delta Y$

$\left.H 2^{\prime}\right) \Delta L=u \Delta Y$

By dividing equation (8) by (2) and equation (9) by (3) the following equation will be obtained:

$\Delta K / K=v \Delta Y / v Y=\Delta Y / Y$

$\Delta L / L=u \Delta Y / u Y=\Delta Y / Y$

Where:

$\mathrm{Y} / \mathrm{Y}=$ output growth rate

$\mathrm{K} / \mathrm{K}$ = capital growth rate

$\mathrm{L} / \mathrm{L}=$ labor growth rate

In a simple economy without government intervention and foreign trade as well as on the condition of the goods market equilibrium then:

$\mathrm{I}=\mathrm{S}$

Savings are obtained from output that is not consumed. Thus, investment is the portion of output that is not consumed. 
From Equation (4), (5), and (8) it can be obtained the equation:

$$
\begin{aligned}
& \Delta K=I=S=s Y \\
& v \Delta Y=\Delta K=I=S=s Y \\
& v \Delta Y=s Y \ldots \ldots \ldots \ldots \ldots \ldots \ldots \ldots \ldots \ldots \ldots \ldots \ldots \ldots \ldots \ldots \ldots \ldots \ldots \ldots \ldots \ldots \\
& v \Delta Y=v Y=s Y / v Y \\
& \Delta Y / Y=s / v
\end{aligned}
$$

So that ICOR can be formulated:

$$
I C O R=\frac{\Delta K}{\Delta Y}
$$

Where:

$$
\begin{aligned}
\mathrm{K}= & \text { Investment or addition of new } \\
& \text { capital goods/capacity } \\
\mathrm{Y}= & \text { Addition of output }
\end{aligned}
$$

The calculation of the increase in output $(\Delta Y)$ is approximated by the increase in Gross Value Added ( $\triangle$ NTB) by business field (Campano et al., 2017). As an example, the increase in agricultural output in 2019 is approached by a reduction in the value of add agriculture in 2019 on a constant price basis with added value agriculture in 2018 at constant prices. With good treatment the same, the increase in output by business field is calculated as the increase in NTB by business field (Soumaila, 2017). The above approach is taken because NTB data is available with time series which is quite long is derived from the calculation of GRDP according to the field effort. In addition, for several business fields whose output is in the form of services, then the calculation of added value will be easier and more precise.

\section{RESULTS AND DISCUSSION}

Over the past five years, the investment structure of D.I. Yogyakarta is dominated by information and communication activities with a contribution of 13.49 percent per year. Other business fields that also invest quite a lot (with a share above 10 percent) are transportation and warehousing at 13.51 percent; construction by 12.61 percent; and accommodation and provision of food and drink by 11.82 percent. Furthermore, other business fields with an average investment contribution of 6-10 percent per year are the manufacturing industry, education services, government administration, and trade. Meanwhile, investment in real estate is 5.82 percent.

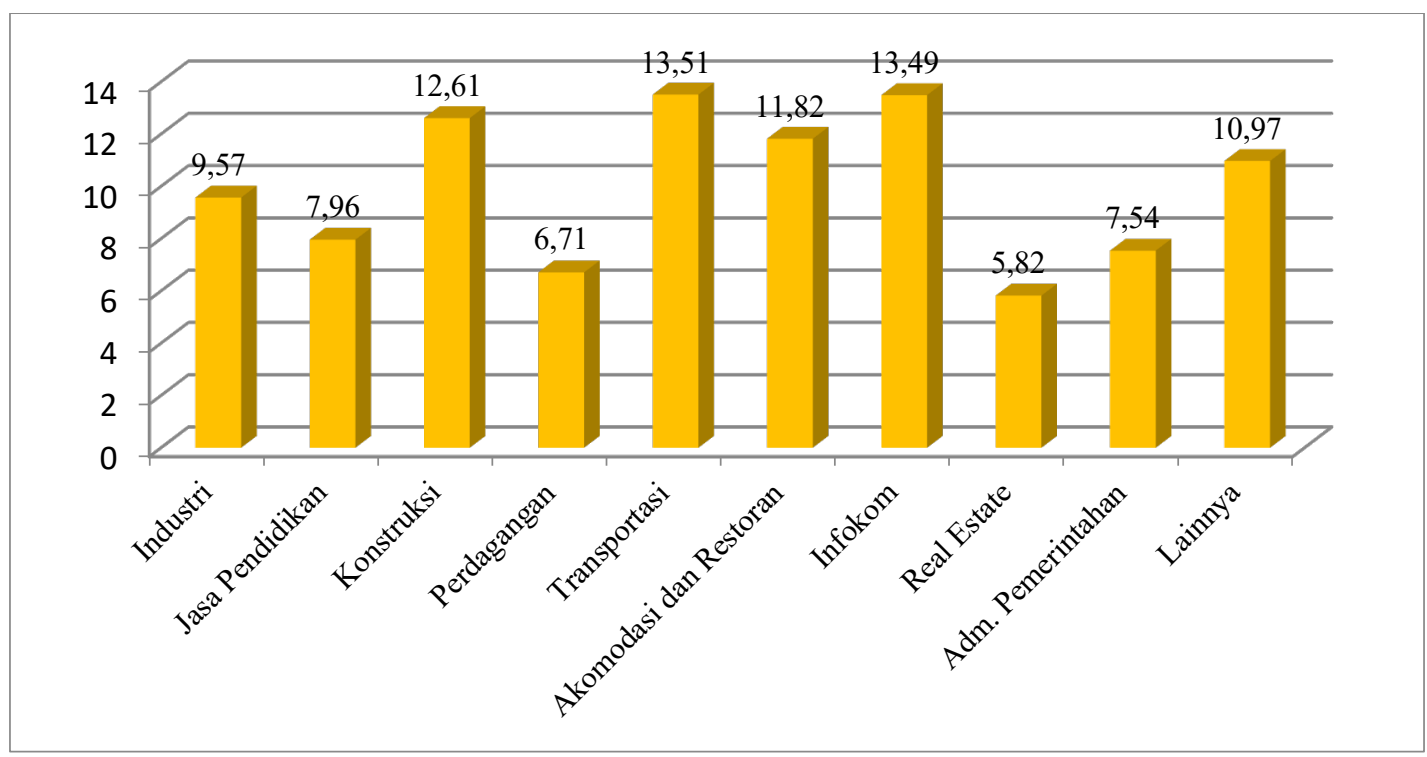

Source: Processed

Figure 1. Average Investment Structure of

D.I. Yogyakarta by Field of Business, 2015-2019 
Furthermore, in terms of industry groups, the average share of the largest investment occurred in the tertiary industry group, which was 75.70 percent, followed by the secondary industry group at 22.70 percent, and the primary industry group at 1.60 percent. The primary industry group is an activity of utilizing natural resources, such as agricultural and quarrying businesses which are only processing natural resources so that investment tends to be small.
The secondary industry group consists of the processing industry, electricity and gas supply, water supply (including waste, waste and recycling management), and construction. Furthermore, the tertiary industry, also known as the service industry, is an economic activity whose production is in the form of services, such as trade, transportation, provision of accommodation and food and drink, information and communication, finance, and other service activities.

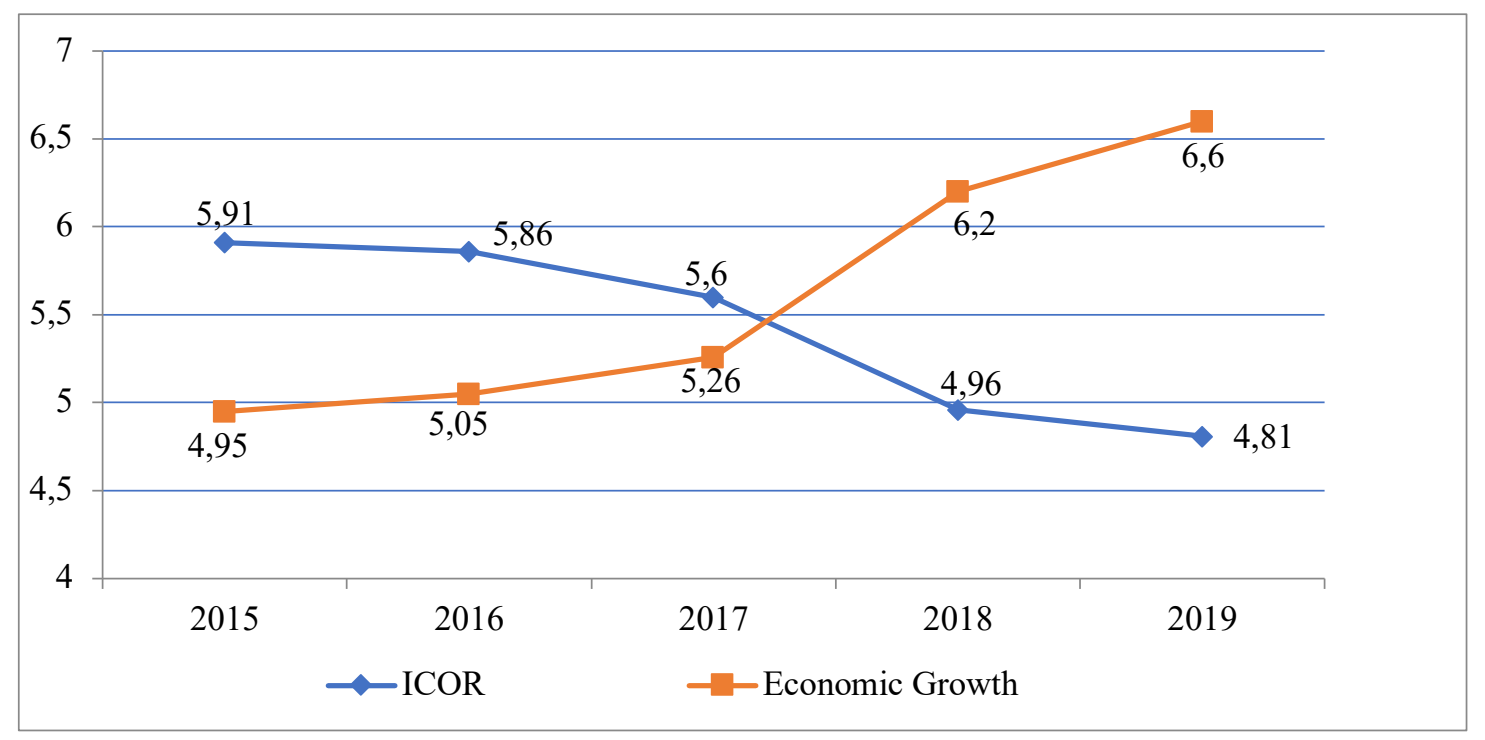

Source: Processed

Figure 2. Relationship between ICOR and Economic Growth of D.I. Yogyakarta, 2015-2019

During the 2015-2019 period, the ICOR D.I. Yogyakarta tends to experience a decline. In 2015 the ICOR D.I. Yogyakarta amounted to 5.91 and continued to decline until it reached the level of 4.81 in 2019. The ICOR figure shows the amount of investment needed to obtain an additional 1 (one) unit of output. Thus, the ICOR figure of 4.81 in 2019 means that to obtain an additional output of 1 billion rupiah, an additional investment of 4.81 billion rupiah is required. Meanwhile, in 2015 the additional investment required to increase output by 1 billion rupiah was 5.91 billion rupiah. If we refer to the existing theory, the large decline in ICOR shows that investment activities in 2019 were more efficient than in previous years. However, caution should be exercised in using ICOR information for policy making. In addition to calculating the total ICOR coefficient, D.I. Yogyakarta, the calculation is also carried out at the district/city level. The highest ICOR in 2019 occurred in Sleman Regency, which was 5.69. Then followed by Gunungkidul Regency with 5.27; Kulon Progo Regency by 4.56; Bantul Regency by 4.54; and the lowest is Yogyakarta City at 4.38.

Other districts/cities in D.I. Yogyakarta. The processing industry in Sleman Regency is generally dominated by the food and beverage industry as well as the textile and apparel industry. The textile 
industry is more capital intensive so it requires a larger investment. Likewise, the construction of hotels, shopping centers, roads, and other buildings is still being carried out and over the last five years its role has also increased.

Table 1. District ICOR in D.I. Yogyakarta with

\begin{tabular}{lcccccc}
\multicolumn{5}{c}{ Investment Approach $=$ PMTB + Change Inventory, 2015 - 2020 } \\
\hline \multicolumn{1}{c}{ District } & $\mathbf{2 0 1 5}$ & $\mathbf{2 0 1 6}$ & $\mathbf{2 0 1 7}$ & $\mathbf{2 0 1 8}$ & $\mathbf{2 0 1 9}$ & $\mathbf{2 0 2 0}$ \\
\hline Kulonprogo & 6,41 & 6,32 & 5,28 & 3,75 & 4,56 & 5,26 \\
Bantul & 4,94 & 4,90 & 4,84 & 4,56 & 4,54 & 4,76 \\
Gunungkidul & 5,53 & 5,55 & 5,38 & 5,32 & 5,27 & 5,41 \\
Sleman & 6,68 & 6,85 & 6,66 & 5,71 & 5,69 & 6,35 \\
Yogyakarta & 5,13 & 5,13 & 4,97 & 4,74 & 4,38 & 4,87 \\
DI. Yogyakarta & $\mathbf{5 , 9 1}$ & $\mathbf{5 , 8 6}$ & $\mathbf{5 , 6 0}$ & $\mathbf{4 , 9 6}$ & $\mathbf{4 , 8 1}$ & $\mathbf{4 , 8 7}$ \\
\hline
\end{tabular}

Source: Processed

The increasing role of construction activities means that more and more capital is invested in these capital-intensive activities so that in the 2015-2019 period, the ICOR in Sleman Regency is always the highest in D.I. Yogyakarta. On the other hand, Yogyakarta City is the region with the lowest ICOR coefficient this year. The economy of Yogyakarta City is dominated by service activities that do not require a large enough capital, such as machinery in the manufacturing industry. The developing service business sector tends to have a relatively low ICOR value.

The development of ICOR, GDI, GDS, economic growth, and inflation rates can be seen in Table 2. There are several main trends from the development of the above indicators. First, from 2015 to 2019 ICOR tends to decline, which means the production process tends to be more efficient. Second, Gross Domestic Investment (GDI) also tends to increase. This is a fairly good signal because it shows the reinvested portion of GDP is increasing. On the other hand, the development of
Gross Domestic Savings (GDS) also tends to increase except in 2017 which has slowed down. With the conditions of GDI and GDS being in opposite directions, the gap between GDI and GDS (I-S Gap) is still quite wide. The IS Gap describes the gap between investment and savings in a region. Thus, the condition where the I-S Gap is quite wide reflects the portion of investment financing from outside D.I. Yogyakarta tends to increase even though in 2019 there was an increase in savings in D.I. Yogyakarta. The larger the I-S gap, the greater the portion of investment that will enter from outside D.I. Yogyakarta. For example, the construction of large hotels, malls or super malls, and most likely the investment comes from outside D.I. Yogyakarta. Coupled with the airport megaproject which is increasingly giving fresh air to investors. Third, there is a tendency for D.I. Yogyakarta has increased during the 2015-2019 period from 4.95 percent in 2015 to 6.60 percent in 2019 . Fourth, there is a tendency for inflation to be at a low level for the last five years.

Table 2. ICOR, GDI, GDS, LPE, and Inflation Yogyakarta 2015-2019

\begin{tabular}{lccccc}
\hline \multicolumn{1}{c}{ Indicators } & $\mathbf{2 0 1 5}$ & $\mathbf{2 0 1 6}$ & $\mathbf{2 0 1 7}$ & $\mathbf{2 0 1 8}$ & $\mathbf{2 0 1 9}$ \\
\hline ICOR & 5.91 & 5.86 & 5.6 & 4.96 & 4.81 \\
GDI & 31.5 & 31.58 & 32.3 & 34.35 & 36.08 \\
GDS & 12.15 & 12.72 & 12.2 & 13.61 & 15.47 \\
LPE & 4.95 & 5.05 & 5.26 & 6.2 & 6.6 \\
IS-Gap (\%) & 19.35 & 18.86 & 20.11 & 20.73 & 20.62 \\
Nominal IS-Gap (Miliar Rp) & 19.626 & 20.739 & 23.951 & 25.929 & 29.152 \\
Inflation & 3.09 & 2.29 & 4.2 & 2.66 & 2.77 \\
\hline
\end{tabular}

Sources: Processed 
The results of calculating ICOR numbers with the assumption that investments made in a certain year will only produce the desired output after one year and the next two years are presented in Table 3. In Table 3, the investment approach is the sum of PMTB and changes in inventory, while Table 3 uses the same investment approach as PMTB only. In total, the results of calculating ICOR numbers with time lag 0 , time lag 1 , and time lag 2, both with and without taking into account changes in inventory, have decreased. The ICOR (Investment $=$ PMTB + Inventory) at time lag 0 is 5.43 to 5.33 (time lag 1), and becomes 5.14 (time lag 2). This indicates that the productivity of capital is increasing or the production process is more efficient as the time of the production process increases. Likewise, the ICOR calculation (Investment $=$ PMTB) also shows the same trend. At time lag 0 the ICOR number is 5.21, then it becomes 5.09 (time lag 1), and becomes 4.91 (time lag 2). When viewed from the large ICOR figure, it can be said that the investment needs are decreasing along with the longer the desired time to obtain benefits from investment activities.

If we look further, there are 10 business fields that experienced a decrease in ICOR in lag-1 and lag-2 when compared to the ICOR value of lag- 0 , namely mining and quarrying; processing industry; electricity and gas procurement; water supply, waste, waste and recycling management; construction; transportation and warehousing; information and communication; financial and insurance services; real estate; and company services. This phenomenon shows that the ten business fields experienced an increase in capital productivity after one or two years.

On the other hand, business fields that experienced a decline in capital productivity were reflected by the increase in the ICOR number, namely agriculture, forestry, and fisheries; wholesale and retail trade, repair of cars and motorcycles; provision of accommodation and food and drink; government administration of defense, and mandatory social security; education services; health services and social activities; as well as other services.

The need for investment decreases as the length of time it is desired to benefit from investment activities increases. If we look further, there are 10 business fields that experienced a decrease in ICOR in lag-1 and lag-2 when compared to the ICOR value of lag- 0 , namely mining and quarrying; processing industry; electricity and gas procurement; water supply, waste management, waste, and recycle; construction; transportation and warehousing; information and communication; financial and insurance services; real estate; and company services. This phenomenon shows that the ten business fields experienced an increase in capital productivity after one or two years. On the other hand, the business fields that experienced a decrease in capital productivity were reflected by the increase in the ICOR number, namely agriculture, forestry, and fisheries; wholesale and retail trade, repair of cars and motorcycles; provision of accommodation and food and drink; mandatory government administration, defense, and social security; education services; health services. 
Table 3. ICOR by Field of Business Standard Method Lag-0, Lag-1, and Lag-2 2015-2019 Investment Approach

\begin{tabular}{clccc}
\hline No & \multicolumn{1}{c}{ Business Field } & Lag-0 & Lag-1 & Lag-2 \\
\hline 1 & Agriculture, Forestry and Fisheries & 2.75 & 3.05 & 3.48 \\
& a. Agriculture, Livestock, Hunting and Agricultural Services & 2.51 & 2.71 & 3.03 \\
& b. Forestry and Logging & 2.58 & 2.71 & 3.01 \\
& c. Fishery & 1.07 & 1.12 & 1.21 \\
2 & Mining and excavation & 2.99 & 2.72 & 2.37 \\
3 & Manufacturing & 4.58 & 3.82 & 3.24 \\
4 & Procurement of Electricity, Gas & 13.73 & 11.72 & 9.66 \\
5 & Water Supply, Waste Management, Waste and Recycling & 5.37 & 4.51 & 3.69 \\
6 & Construction & 4.38 & 3.99 & 3.62 \\
7 & Wholesale and Retail Trade, Car and Motorcycle Repair & 2.09 & 4.36 & 4.48 \\
8 & Transportation and Warehousing & 15.47 & 14.24 & 13.15 \\
9 & Provision of Accommodation and Food and Drink & 5.58 & 6.17 & 6.67 \\
& a. Accommodation Provision & 3.64 & 3.99 & 4.32 \\
& b. Food and Drink Preparation & 6.52 & 7.26 & 7.85 \\
10 & Information and Communication & 5.41 & 4.81 & 4.2 \\
11 & Financial Services and Insurance & 2.79 & 2.68 & 2.59 \\
& a. Financial Intermediary Services & 2.22 & 2.08 & 1.97 \\
& b. Other Services & 4.08 & 3.94 & 3.82 \\
12 & Real Estate & 4.26 & 4.11 & 3.98 \\
13 & Company Services & 5.03 & 4.85 & 4.7 \\
14 & Government Administration, Defense and Mandatory Social & & & 6.33 \\
& Security & 4.66 & 5.48 & 6.72 \\
15 & Education Services & 5.02 & 5.46 & 5.3 \\
16 & Health Services and Social Activities & 5.85 & 5.27 & 5.51 \\
& Other services & $\mathbf{5 . 2 1}$ & $\mathbf{5 . 0 9}$ & $\mathbf{4 . 9 1}$ \\
\hline
\end{tabular}

Sources: Processed

\section{CONCLUSIONS}

Invest in D.I. Yogyakarta during the observation period continued to increase. In 2015 the investment value was recorded at 31.95 trillion rupiahs at current prices and 23.26 trillion rupiahs at constant 2010 prices. Then, in 2019 it increased to 51.02 trillion rupiahs at current prices and 31.11 trillion rupiahs. based on constant 2010 prices. In terms of the amount of contribution, 5 (five) business fields that contributed the largest during the 20152019 period, respectively, were information and communication business fields of 13.49 percent; followed by transportation and warehousing by 13.51 percent; construction by 12.61 percent; provision of accommodation and food and drink around 11.82 percent; and other services by 10.97 percent. Meanwhile, for other business fields, the contribution ranges from 6 to 10 percent. If viewed from the spatial side, on average the largest investment occurred in Sleman Regency with a contribution of around 40.21 percent per year; followed by Yogyakarta City, Bantul Regency, Gunungkidul Regency, and Kulon Progo Regency with each contribution of 22.40 percent; 15.17 percent; 11.69 percent; and 10.52 percent.

During the 2015-2019 period, economic growth of D.I. Yogyakarta averages 5.77 percent per year. The business fields with the highest average growth rate are construction, which grows by 9.91 percent per year; followed by information and communication by 7.09 percent; provision of accommodation and food and drink by 6.84 percent; and electricity and gas procurement by 6.65 percent. Meanwhile, the business fields with the lowest average growth rate were agriculture, forestry, and fisheries, which grew 1.64 percent per year. Other business fields grow in the range of 4-5 percent per year.

The result of calculating the total ICOR of D.I. Yogyakarta in 2019 was 4.81 . 
This ICOR figure is relatively lower than the previous year which was 4.96. On the other hand, the economic growth rate in 2019 reached 6.60 percent, a significant increase compared to 2018 which reached 6.20 percent. When compared to ICOR of other provinces in the Jabalnusra area, ICOR D.I. Yogyakarta is the lowest, as well as when compared to the national ICOR figure of 7.11. The results of ICOR calculations using both standard and accumulated methods, with and without taking into account changes in inventory, produce figures that are not much different. Business fields with ICOR below level 4 are: agriculture, forestry, and fisheries; mining and excavation; wholesale and retail trade, repair of cars and motorcycles; financial and insurance services; as well as real estate. Meanwhile, the business fields with ICOR above 10 are electricity and gas procurement as well as transportation and warehousing.

\section{REFERENCES}

Campano, F., Laureti, L., \& Salvatore, D. (2017). Capturing the effects of changing capital-intensity on Long-term growth in the major emerging economies. Journal of Policy Modeling, 39(4), 729-740. https://doi.org/10.1016/j.jpolmod. 2017.05.018

Ehigiamusoe, K. U., \& Lean, H. H. (2019). Do economic and financial integration stimulate economic growth? A critical survey. Economics, 13, 1-27. https://doi.org/10.5018/economics -ejournal.ja.2019-4

Huggins, R., Izushi, H., Prokop, D., \& Thompson, P. (2014). Regional competitiveness, Economic growth and stages of development. Zbornik Radova Ekonomskog Fakulteta u Rijeci: Časopis Za Ekonomsku Teoriju i Praksu, 32(2), 255-283.

Jiang, Y., Jiang, Y., \& Zheng, J. (2019). Investment in Infrastructure and
Regional Growth in China.

Emerging Markets Finance and

Trade, $0(0), \quad 1-15$.

https://doi.org/10.1080/1540496X

.2019 .1627195

Mahmud, M. (2008). Incremental Capital Output Ratio: Barometer Efisiensi Perekonomian Nasional. Jurnal Ilmiah Ekonomi Bisnis, 13(1), 5892.

Maradana, R. P., Pradhan, R. P., Dash, S., Zaki, D. B., Gaurav, K., Jayakumar, M., \& Sarangi, A. K. (2019). Innovation and economic growth in European Economic Area countries: The Granger causality approach. IIMB Management Review, 31(3), 268282.

https://doi.org/10.1016/j.iimb.201 9.03.002

Masloman, I. (2020). Analisa Perhitungan ICOR di Kabupaten Minahasa Tenggara. Jurnal Berkala Ilmiah Efisiensi, 20(02).

Nevyantseva, L., \& Vlasova, N. (2021). Comparative Analysis of Methods for Evaluating Efficiency of Regional Investment Policy. In SHS Web of Conferences (Vol. 93). EDP Sciences.

Ru, S., Liu, J., Wang, T., \& Wei, G. (2020). Provincial quality of economic growth: Measurements and influencing factors for China. Sustainability (Switzerland), 12(4).

https://doi.org/10.3390/su1204135 4

Samoylova, K. N., Myzaev, M. Z., Rykina, S. N., Denisova, I. P., \& Takmazyan, A. S. (2020). Regional Investment Policy in The Context of Economic Growth, Employment and Income of the Population. International Journal of Economics \& Business Administration (IJEBA), 8(4), 691699. 
Sedova, N. V., \& Filatov, A. S. (2020). Improving the Efficiency of Managing Regional Investment Projects. Regionalnaya ekonomika. Yug Rossii, 130-138.

Soumaila, I. (2017). The Determinants of Investment Efficiency in West African Economic and Monetary Union (Waemu). The Journal of Developing Areas, 51(1), 49-61. https://doi.org/10.1353/jda.2017.0 003
Thach, N. N. (2020). Endogenous economic growth: The arrow-romer theory and a test on vietnamese economy. WSEAS Transactions on Business and Economics, 17, 374-386. https://doi.org/10.37394/23207.20 20.17 .37

Walters, A. A. (1966). Incremental capitaloutput ratios. The Economic Journal, 76(304), 818-822. 